\title{
O LÉXICO FILOSÓFICO DE ARISTÓTELES (II): COMENTÁRIOS A METAFÍSICA V.9-17
}

\author{
Lucas Angioni \\ Universidade Estadual de Campinas
}

Resumo: Eu examino cada meandro do esforço de Aristóteles identificar vários usos de termos filosóficos essenciais em sua Metafísica, V.9-17.

Palavras-chave: Metafísica, Léxico Filosófico, Metodologia, Aristóteles.

Abstract: I examine each meander of Aristotle's effort to identify several uses of key philosophical terms in his Metaphysics, V.9-17.

Keywords: Metaphysics, Philosophical Lexicon, Methodology, Aristotle.

\section{Introdução}

O livro V (Delta) da Metafísica de Aristóteles tem a aparência de um léxico filosófico e foi assim tomado na tradição filosófica ocidental. Em vez de continuar a desenvolver argumentos sobre a ciência dos primeiros princípíos, como fizeram os livros precedentes, o livro $\mathrm{V}$ da Metafísica apresenta uma sucessão de capítulos nos quais certos termos importantes do vocabulário filosófico são escrutinados. No entanto, compará-lo a um léxico filosófico contemporâneo é enganador, impróprio e decepcionante. Em primeiro lugar, Aristóteles não parece seguir um plano previamente determinado para estruturar cada capítulo. Ao contrário, os capítulos são bem diferentes entre entre si, sendo alguns mais completos, outros bem mais sucintos. Os capítulos mais completos (entre os quais se poderia indicar, por exemplo, o capítulo 2, sobre as causas, bem como o capítulo 12, sobre a dynamis) listam usos ordinários do termo na língua comum, eventualmente remetem a usos específicos introduzidos em determinado ramo do saber, identificam usos mais importantes e usos claramente metafóricos, esboçam alguma sistematização sobre os diversos usos, procurando explicar certa unidade que dá um pouco de coesão à diversidade de usos etc. Outros capítulos, no entanto, se limitam a listar diversos usos das expressões em questão, sem nem sequer compará-los entre si, sem esboçar nenhuma reação quanto às sobreposições extensionais de diversas definições, sem indicar nenhuma direção que pudesse hierarquizar e 
sistematizar os diversos usos. Em todos eles, é raro encontrar alguma indicação sobre qual uso é o mais importante para a filosofia de Aristóteles ou, ao menos, para o argumento central desenvolvido na Metafísica (pois, como Stephen Menn vem procurando mostrar, há um argumento central desenvolvido na Metafísica). Em segundo lugar, a lista de Aristóteles está longe de ser exaustiva. Alguns termos extremamente importantes de sua filosofia não são objeto de nenhuma elucidação. As ausências mais flagrantes são o termo

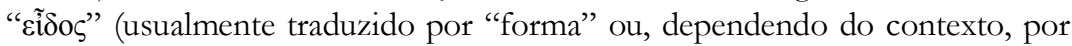
"espécie"), o termo " $v \lambda \eta \eta$ " (normalmente traduzido por "matéria") e os termos

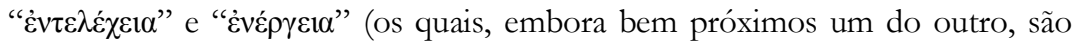
distintos, e usualmente traduzidos por "ato" - resquício escolástico que beira o non-sense -, "atualidade", "atividade" ou "efetividade"). Essas ausências são bem significativas se considerarmos que boa parte dos argumentos nos livros centrais da Metafisica desenvolvem a assim chamada teoria hilemórfica, e que os livros finais (XII-XIV), ao se ocupar da existência de substâncias suprasensíveis, dependem fundamentalmente dos conceitos introduzidos pelos

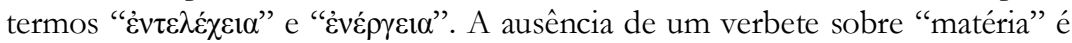
particularmente de se lamentar, pois muitas querelas em torno do hilemorfismo depende de confusões e sutilezas envolvendo o uso desse termo.

De tudo isso, resulta uma conclusão metodológica de extrema importância. Alguns leitores poderiam tomar o léxico contido no livro $\mathrm{V}$ da Metafisica como um importante critério para controlar hipóteses interpretativas. Essa estratégia deve ser limitada, porém, à sua parte positiva. $\mathrm{O}$ intérprete pode sentir-se seguro e aliviado se o livro V da Metafísica registra, para uma dada expressão, um uso específico do qual depende sua reconstrução de uma determinada passagem. No entanto, a estratégia é totalmente inútil se for usada em uma contraparte negativa. Se, para compreender os argumentos de Aristóteles em um dado contexto específico, um intérprete propõe que determinada expressão é usada naquele contexto com a acepção $A$, é péssima estratégia de discussão buscar refutá-lo dizendo que aquele uso da expressão, na acepção $A$, não é reconhecido por Aristóteles, porque não se encontra identificado no livro $\mathrm{V}$ da Metafísica. As razões para desqualificar essa estratégia de discussão são várias. Algumas já foram indicadas: as omissões de termos centrais, como "Eĩosos"; o caráter episódico e desleixado de vários capítulos etc. Mas, além dessas razões, há também outra: há contra-exemplos bem proeminentes, isto é, há evidências de que determinados usos de uma expressão se encontram bem sedimentados no texto de Aristóteles, sem que o livro V da Metafísica os tenha identificado. Para mencionar apenas alguns exemplos, podemos mencionar a distinção cuidadosa que Aristóteles faz entre dois níveis de dynamis, correlacionados a dois níveis de entelecheia, em De Anima 
II.5 e outras passagens. No capítulo 12 do livro V da Metafísica, há, no máximo, uma alusão a tais distinções, em 1019b18-19. Outro caso: nos Primeiros Analíticos, Aristóteles faz distinção bem clara entre a necessidade da conseqüência, que caracteriza um argumento dedutivo, e a necessidade enquanto propriedade modal de predicações. De novo, não há nenhum sinal disso no capítulo 5 do livro V da Metafísica.

Apresentamos, como resultado parcial de nossa pesquisa sobre o livro V da Metafísica, a tradução dos capítulos 9-17. Tradução dos capítulos 1-8 foi previamente publicada em 2003, no volume 3 da Revista Phaos (Revista de Estudos Clássicos), p. 5-21.

\section{Comentários ao livro V da Metafísica de Aristóteles (capítulos 9-16)}

\section{Capítulo 9}

Este capítulo deve ser comparado com Tópicos I.7 e diversas outras passagens de Metafísica X (por exemplo, 1054a32-b3). Para uma visão de conjunto sobre as correspondências e pequenas diferenças entre o tratamento do mesmo ponto nos diversos textos, ver Ross [1924], p. 311-2.

1017b27-1018a4: "certas coisas se dizem as mesmas por concomitância": o que Aristóteles discute nesse parágrafo se encontra no plano da linguagem. É claro que o comportamento da linguagem depende do modo pelo qual ela se relaciona à realidade, mas nem por isso se pode dizer que Aristóteles estivesse primariamente interessado, nesse parágrafo, em mapear relações ontológicas (em vez de relações semânticas entre expressões). A rigor, o que Aristóteles quer dizer é que o termo "claro" e o termo "musical" expressam, em dada situação, o mesmo, porque as propriedades a que eles remetem no plano da realidade são atributos de uma mesma coisa ou concorrem em uma mesma coisa. É claro que essa tese depende de uma ontologia - por exemplo, depende da distinção entre substâncias e atributos. No entanto, o foco da tese são as relações semânticas entre termos (ou descrições) que são usados para expressar o mesmo conteúdo. Assim, em uma dada circunstância particular em que estamos interessados em um indivíduo que tem a pele clara e a propriedade de ser musical (i.e., tem habilidade musical, ou é músico de profissão, ou seja lá o que for - pois o mesmo vale para interpretações menos literais do adjetivo grego "mousikon"), os termos "ser humano", "claro" e "musical" podem ser - e efetivamente são - usados na linguagem comum para remeter à mesma entidade, a saber, o ser humano particular no qual estamos interessados. É apenas isso que Aristóteles está descrevendo nesse parágrafo. Isso não quer dizer que as escolhas de Aristóteles para descrever a semântica da linguagem comum não dependam de 
pressupostos ontológicos. Mas, mesmo assim, o que Aristóteles faz nesse parágrafo é apenas descrever um fenômeno lingüístico recorrente: o uso de dois (ou mais) termos gerais para nos referir a um mesmo indivíduo que tem as propriedades denotadas por tais termos.

O ponto de partida de Aristóteles consiste em descrever o fenômeno no caso de dois adjetivos que expressam propriedades não-essenciais de indivíduos humanos, "claro" e "musical" (1017b27-28). Mas, em seguida, Aristóteles descreve o mesmo fenômeno envolvendo termos de categorias heterogêneas - "ser humano" e "musical" (1017b29) -, bem como expressões complexas e seus componentes (1017b30-33). No final das contas, seu ponto é ilustrar o seguinte. Havendo um indivíduo humano que é claro e também musical, é o mesmo indivíduo que é indicado pelo uso de várias expressões "o ser humano", "o claro", “o musical”, "o ser humano musical” etc. O uso desses termos remete à mesma coisa graças a pressuposições contextuais partilhadas por nossos interlocutores - para evidência de que Aristóteles era sensível a pressuposições contextuais partilhadas, cf. Tópicos 103a29-39. Precisamente devido a essa limitação contextual, essas equivalências semânticas não podem ser generalizadas (1017b33-5). No contexto particular em que são usadas, essas expressões se referem ao mesmo indivíduo, de modo que se pode dizer "o homem [sc. Sócrates] é musical". No entanto, não se pode dizer que "todo homem é musical". A rigor - isto é, de modo principal, ou sem cláusulas qualificativas $(\dot{\alpha} \pi \lambda \tilde{\omega} \varsigma)$-, predicados acidentais são aplicados a indivíduos como Sócrates em virtude de algo que lhes ocorre singularmente (1018a1-2).

As observações de Aristóteles sobre "o mesmo por concomitância" coincidem perfeitamente com as observações sobre "um por concomitância" em Metafísica V.6, 1015b16-34. De fato, as condições pelas quais dizemos que expressões "X", "Y" etc. designam a mesma coisa coincidem com as condições pelas quais dizemos que expressões " $\mathrm{X}$ ", " $\mathrm{Y}$ ” etc. designam uma só coisa.

Para exame da questão, ver Castelli [2010], p. 263-4.

1018a4-5: "de tantos modos como se diz 'um"': compare esta passagem com Tópicos I.7, no qual também se encontra uma associação entre ser o mesmo e ser um. As classificações oferecidas em cada uma das passagens são diferentes, mas nem por isso devem ser tomadas como incompatíveis, ou como expressão de momentos distintos na evolução do pensamento de Aristóteles etc. Para exame de Tópicos I.7, ver Smith [1997], p. 68-71, Castelli [2010], p. 260-3. A lista oferecida em 1018a4-9 é mais sucinta que a lista de Tópicos I.7, mas em compensação inclui um caso não contemplado nos Tópicos: o caso em que se diz que duas coisas são a mesma por terem a mesma matéria (por exemplo, se pode dizer que tapioca e polvilho são a mesma coisa - a saber, mandioca). Alguém poderia argumentar que esse tipo de identidade 
segundo a matéria equivale ao tipo que, nos Tópicos, Aristóteles identifica com o exemplo da água da mesma fonte (103a14-23). No entanto, embora sejam similares, esses tipos de identidade são distintos entre si. Aristóteles associa a água da mesma fonte aos casos em que dizemos que coisas são a mesma em virtude de semelhanças em forma.

É também digno de nota que Aristóteles oferece várias definições para a expressão "as mesmas" e não parece interessado em identificar qual delas teria prioridade, tampouco indica qual é a relação entre as mesmas. $\mathrm{O}$ mesmo ocorre para as demais expressões no capítulo ("diversas", 1018a9-11, “diferentes", 1018a12-15, “semelhantes", 1018a15-18). Além do mais, como foi notado por Ross [1924], p. 312, e Kirwan [1993], p. 151, a lista de modos pelos quais se usa a expressão "diversas" não tem (como seria de se esperar) uma correspondência estrita com a lista de modos pelos quais se usa a expressão "as mesmas".

1018a9-11: "as coisas cujas formas são mais de uma, (...) ou cujas definições da essência são mais de uma": em muitos casos, Aristóteles trata a

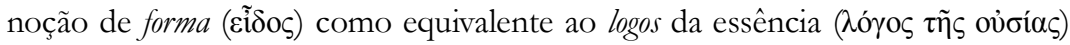
- por exemplo, em Geração dos Animais 715a5ss. - mas aqui em 1018a9-11 o termo "forma" provavelmente é usado em acepção mais fraca, como equivalente a configuração visual, ou algo assim. Essa acepção mais fraca do termo "forma" (દĩosos) é muito comum na obra biológica de Aristóteles.

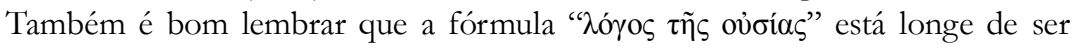
transparente e trivial. Há evidências que fundamentam sua tradução por "definição da essência", em que o genitivo ("da essência") é objetivo e se refere ao conteúdo total da definição. No entanto, é possível tomar " $\lambda$ óyoc" em sentido mais forte, como se referindo ao fator explanatório mais determinante, de tal modo que dizer que a forma de $X$ é o $\lambda$ óyos da essência de $X$ significa dizer que a forma é o fator explanatório mais determinante na essência de $X$, aquele que determina que a essência de $X$ seja como ela é. Por outro lado, nada impede (a não ser os contextos de uso da expressão) tomar o genitivo ("da essência") como subjetivo ou possessivo ("o logos que a essência tem").

1018a12-13: "as coisas que são diversas, mas que são, de certo modo, o mesmo (não apenas em número etc.”: não há nenhuma dificuldade em compreender como duas coisas podem ser diversas, mesmo sendo uma só em número. Alexandre (378.30-35) não percebe o ponto e concebe de outro modo,

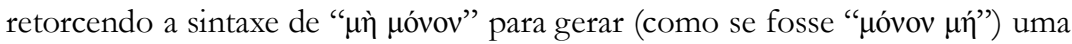
cláusula restritiva desnecessária e errônea: "contato que não seja um só em número". Alexandre julga que "coisas que são idênticas em número não mais

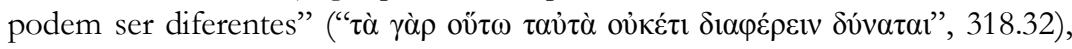
mas esse juízo é falso (e Alexandre parece ter se deixado levar pelo sentido bem 
técnico de "diferente", usado em correlação com classes específicas em um gênero). Ora, um indivíduo como Sócrates é um só em número, mas ele pode ser tomado diferentemente enquanto músico e enquanto soldado etc. Aristóteles concebe essas distinções intensionais de modo claro. Por exemplo, um médico pode curar-se a si mesmo, mas não é enquanto médico que ele é suscetível de ser curado (cf. Física 192b23-27). Trata-se do mesmo indivíduo médico (que é um só e o mesmo em número), e se diz que o indivíduo enquanto médico é diferente do indivíduo enquanto curável. Essas distinções intensionais não apenas são comuns em Aristóteles, como estão na base de muitas teses importantes de sua filosofia.

O deslize de Alexandre repercute em Ross [1924], p. 313 e Kirwan [1993], p.151.

1018a13-15: “denominam-se 'diferentes', ainda etc.”: há várias sobreposições entre os sentidos listados. Sobre isso, Ross [1924], p. 313 tem toda razão quando afirma (contra as reclamações de Bonitz): "It is [...] no part of Aristotle's object to avoid cross division. He is simply giving the statements that might naturally be given of the meaning of 'difference', and if these overlap it is his business to state them nevertheless". O advérbio "naturally" empregado por Ross pode dar margem a outras reclamações, mas creio que Ross quer dizer (e nisto ele está totalmente correto) que Aristóteles apenas está listando e reportando modos pelos quais as expressões são ordinariamente usadas na língua (seja por todos os falantes da língua, seja por um subgrupo específico).

\section{Capítulo 10}

Este capítulo deve ser comparado com Categorias 10 e Metafísica X.3-4. Várias distinções feitas no capítulo se sobrepõem entre si, o que indica fortemente que o propósito de Aristóteles não consiste em regimentar o uso dos termos examinados, mas apenas listar distinções de modo preliminar. ${ }^{1} \mathrm{O}$ enunciado que estabelece um dos sentidos de "opostos" também serviria para definir um dos sentidos de "contrários": "os extremos a partir dos quais se dá o vir a ser e em direção aos quais se dão as corrupções" (cf. algo similar em Física 188b21-23). Aristóteles, de fato, muitas vezes usa esses termos ("opostos" e "contrários") de modo indistinto (cf. Física 188b11, 15; 190b 13, 15). Muitas vezes, Aristóteles usa "opostos" (ou cognatos) no sentido de

\footnotetext{
${ }_{1}^{1}$ Ross [1924], p. 314, diz acertadamente: "If we remember that Aristotle is jotting down the usages of 'opposite' in ordinary speech, we shall find no difficulty in a divergence from his own scientific classification".
} 
"contraditórios" (cf. Primeiros Analíticos II.8-13, 59b6 ss.). O uso que Aristóteles faz desses termos é sensível ao contexto - extremamente sensível ao contexto. É coerente e natural que Aristóteles, em Metafísica V, não tenha o propósito de regimentar o uso desses termos.

1018a25-31: Aristóteles oferece cinco definições para "contrários" e não indica qual delas teria prioridade, tampouco indica qual é a relação entre as mesmas. Do ponto de vista extensional, há sobreposições variadas entre os itens cobertos por cada definição, mas Aristóteles está longe de julgar que isso seja um problema. Cada definição é apropriada a seu contexto de aplicação.

Para efeito de comparação, ver Categorias 12b26-13a31, 13b36-14a25; Tópicos 123b1-37; Metafísica X.4-7.

1018a31-35: “ou por possuir propriedades desse tipo etc.": nesta passagem, bem como em outras (cf. 1022a1-3), Aristóteles adota o mesmo princípio usado em Metafísica IV.2, 1003a33-b10, ao apresentar o modo pelo qual as coisas se denominam entes. Como se sabe, desde Owen [1957], esse princípio foi chamado de teoria do sentido focal (focal meaning) do "ser". O que talvez não se sabe com a devida ênfase é que esse princípio está fortemente enraizado na observação de como a linguagem ordinária se comporta. Cf. Shields [1999], p. 36-39, para exame da passagem-chave de Metafísica IV.2.

1018a35-38: ver ponto similar em Metafisica IV, 1004a22-30. Nesta passagem, os termos "um", "ente", "mesmo", "outro" e "contrário" são claramente mencionados (em vez de usados).

1018a38: “diversas em espécie": "betera toi eidel" poderia ser igualmente traduzido por "diversas em forma", mas, neste contexto, o contraste de "eidos" com o termo correlato "genos" ("gênero") parece-me impor "espécie" como uma tradução preferível.

1018a38-b7: Aristóteles oferece seis definições para a expressão "diversas em espécie" e, tal como ocorrera em 1018a25-31 em relação ao termo "contrários", não parece interessado nem em indicar qual dessas definições teria prioridade, nem em explorar suas diferenças. Do ponto de vista extensional, as definições envolvem várias sobreposições, mas Aristóteles não parece julgar que isso seja indesejável. Para exame mais completo do tema, ver Metafisica X.8-9.

1018b4-5: "que estão em uma última espécie do gênero": traduzi o que temos no texto grego, mas a expressão é bizarra e suscita uma apóstrofe de Ross em seu aparato crítico (bem como em seu comentário, ver Ross [1924], p. 316). Seria de se esperar que Aristóteles dissesse, antes, "que são espécies últimas do gênero".

1018b6-7: "também são diversas em espécie as coisas que, estando na mesma substância, possuem diferença”: o termo "oủoía” em 1018b7 parece ser 
mais bem traduzido por "substância" (em vez de "essência"), mas o fato é que a asserção de Aristóteles é tão vaga que não dá para decidir de modo definitivo. Aristóteles parece se referir a atributos que estão presentes na mesma substância, mas são diferentes entre si (como o quente e o frio, que, sendo diferentes, podem estar presentes no ferro, cf. Ross [1924], p. 316). No entanto, nada impede tomar "oủoía" no sentido de essência e entender a passagem como remetendo a diferentes itens que compõem a essência de algo. $\mathrm{Na}$ essência do trovão, por exemplo, estão presentes tanto o substrato nuvem como a causa extinção do fogo, e ambos esses itens são claramente diferentes. Neste caso, porém, a expressão traduzida por "diversas em espécie" deveria ser entendida e traduzida como "diversas em forma".

\section{Capítulo 11}

Este capítulo deve ser comparado com Categorias 12, texto no qual Aristóteles também se dedica a discernir diversos usos de "anterior" e "posterior" (e, portanto, diversas noções de prioridade). As duas listas têm semelhanças significativas entre si (cf. Ross [1924], p. 317), mas as diferenças são também notáveis. É surpreendente que o capítulo da Metafísica não considere a prioridade causal, que recebe bastante atenção nas Categorias (14b10-22) e é um dos conceitos centrais da filosofia da ciência de Aristóteles (cf. Segundos Analiticos II.16-17).

1018b22-23: "anteriores pelo poder: aquilo que excede em poder é

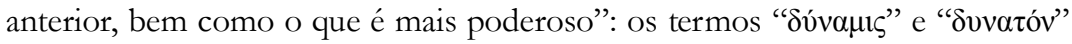
serão objeto do capítulo seguinte, no qual predomina o uso dos termos para designar a capacidade de fazer ou sofrer algo, mas, nesta passagem do capítulo 11, os termos são empregados no sentido mais estrito de poder, como fica claro na seqüência.

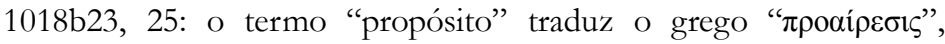
usualmente traduzido por "escolha", "decisão", etc. Justifiquei minha opção por "propósito" em Angioni [2011].

Dado que Aristóteles considera que apenas seres humanos têm propósitos - pois o propósito envolve especificar por meio da deliberação os fins acolhidos pelo desejo -, é inusitado que Aristóteles use o gênero neutro, em 1018b23-24, para falar das coisas que têm propósitos.

1018b31-34: "aquilo que é anterior pelo conhecimento": Aristóteles apenas assinala que as coisas podem ser identificadas como anteriores pelo conhecimento de dois modos, mas não se aprofunda no assunto. A prioridade ou anterioridade pelo conhecimento é assunto muito mais complexo: (i) pode haver uma prioridade apenas quanto à compreensão das expressões, ou quanto à apreensão de que proposições são verdadeiras (Segundos Analíticos 71b31-33 e 
71a12-17); (ii) há uma prioridade na ordem da descoberta, para nós, em oposição a uma prioridade por natureza (Segundos Analíticos 71b33-72a5, Metafisica 1029b3-12); (iii) a prioridade por natureza, nesse sentido estrito, parece equivalente à prioridade causal (Categorias 14b10-22), mas não se confunde com a prioridade segundo a implicação (Categorias 14a29-35), (iv) tampouco é claro se esta prioridade segundo a implicação se identifica com a prioridade das premissas sobre uma conclusão válida. Etc.

Longe de desenvolver o assunto e, mais importante, longe de dar uma lista razoavelmente completa de modos pelos quais se concebe a prioridade pelo conhecimento, Aristóteles apenas anota dois sentidos muito triviais: a prioridade de acordo com a apreensão sensível, e a prioridade de acordo com o logos. Esta última é controversa, porque Aristóteles a caracteriza de modo

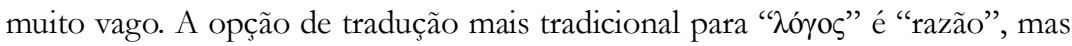
neste contexto Aristóteles muito provavelmente usa " $\lambda$ ó $\gamma$ o $"$ " apenas para assinalar o uso que fazemos da linguagem articulada (cf. também 1018b34-36,

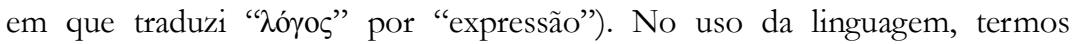
universais têm prioridade no sentido de que objetos singulares são apreendidos e classificados por meio deles.

1018b34-7: na sentença "musical" é anterior a "homem musical" (1018b35), Aristóteles está falando das expressões "musical" e "homem musical" (por isso, usei as aspas para demarcar que as expressões são mencionadas, mas não usadas): a primeira é anterior à segunda simplesmente por ser parte dela. Em interpretação bem deflacionada, "logos" em $1018 b 36$ pode ser tomado no sentido trivial de expressão composta (cf. Tópicos 102a1-2). A tradução resultante é esta: "pois a expressão [sc. "homem musical"] não será inteira sem a parte [sc. "musical"]". Conseqüentemente, também em 1018b34 "logos" deve ser tomado como expressão: é de acordo com a expressão lingüistica que o concomitante é anterior ao todo. Já do ponto de vista de como as coisas realmente são, as relações de prioridade são diferentes. (Kirwan [1993], p. 154, parece sugerir uma intepretação nessa mesma linha). Como Aristóteles explica na sentença concessiva em 1018b36-7, é impossível que $X$ seja musical sem ser algo musical: $X$ é, antes de tudo, algo que se classifica previamente sob algum predicado sortal, que identifica o receptáculo apropriado da propriedade de ser musical (cf. a mesma tese em Segundos Analiticos 83a31-32, b20-23).

No entanto, é razoável supor que "logos" em 1018b34, 36 seja usado no sentido de definição - o tipo de definição que apenas especifica o sentido de uma expressão (pois há definições desse tipo, cf. Segundos Analíticos 93b30-32, Metafisica 1030a14-16). Se for assim, Aristóteles está a considerar que, se alguém for definir o sentido da expressão "homem musical", ou de outra expressão equivalente a ela (cf. Metafísica 1029b27-28), será parte de tal 
definição o termo "musical" ou a definição que explicita o sentido de "musical", mas não o inverso, isto é, nenhuma remissão a "homem musical" precisa ser feita para definir o sentido da expressão "musical".

1019a2-4: “anteriores por sua natureza e essência etc.": esta noção de prioridade é decisiva para compreender os meandros da Metafísica de Aristóteles. Análise excelente e pormenorizada se encontra em Peramatzis [2008] e [2011], p. 204-8. Meu ponto de vista (em Angioni [2010]) é bem próximo ao de Peramatzis e devo muito a ele (sobretudo ao rejeitar a interpretação desse tipo de prioridade em termos de meras relações de existência dos relata), mas discordo dele por julgar que o tipo de prioridade que Aristóteles define nestas linhas não é fundamental para a parte construtiva de sua metafísica. Ao contrário, esse tipo de prioridade, delimitado pelo critério da synanairesis (cf. Angioni [2008], p. 32ss.), atribuído a Platão e seus seguidores, é identificado como fonte de muitos deslizes em suas teorias. Meu ponto de vista é mais próximo do de Stephen Menn, que, em seu manuscrito ainda não publicado sobre a Metafisica (The aim and the argument of the Metaphysics) identifica esse critério de prioridade com a expressão "Plato's test". Para outra interpretação, diferente da de Peramatzis e da minha, ver Makin [2003] e [2006], p. 192-6.

1019a5-6: "a substância é anterior": esta ocorrência de "oủ $\sigma i ́ \alpha "$ (1019a6, bem como em 1019a9) me parece mais bem traduzida por "substância" (em vez de "essência"), devido à associação explícita com a noção de subjacente e com a noção de subsistir efetivamente em si mesmo.

1019a6-11: "em seguida, são anteriores de modos diversos etc.": esta passagem é bem difícil e obscura. Para análise pormenorizada e cuidadosa, ver Peramatzis [2011], p. 223-228, e Coope [2005], p. 68-69. A tradução também é extremamente difícil, pois Aristóteles usa de modo consistente um único par

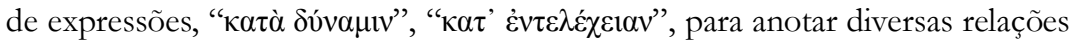
de prioridade, mas é muito difícil encontrar equivalentes em Português que sejam convenientes em todas as ocorrências. Além do mais, é difícil discernir se os tipos de prioridade assim identificados se relacionam ou não com a classificação atribuída a Platão em 1019a2-4.

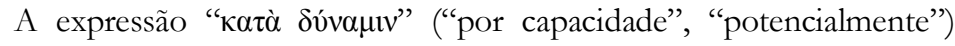
assinala uma prioridade que a parte tem sobre o todo e a matéria tem sobre a substância. De fato, Aristóteles por vezes aplica o teste da prioridade por natureza e essência (a classificação atribuída a Platão em 1019a2-4) para identificar a parte como anterior ao todo e a matéria como anterior à

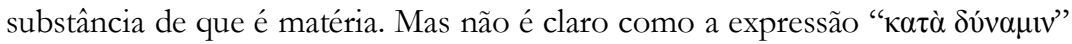

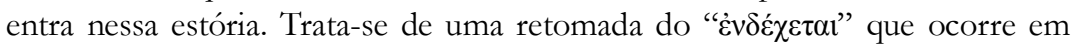
1019a3? Aristóteles quer assinalar que a matéria pode (isto é, tem o poder de) 
subsistir sem a substância de que é matéria, mas não vice-versa? Se é assim, o

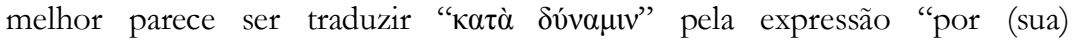
capacidade". No entanto, a expressão " $\kappa \alpha \tau$ ' $\dot{v} \tau \varepsilon \lambda \dot{\varepsilon} \chi \varepsilon 1 \alpha v$ " entra na estória para assinalar outro lado: quando uma substância existe plenamente sendo o que ela é, algumas de suas partes materiais não podem ser efetivamente o que são, nem ser identificadas corretamente, sem o todo da substância a que pertencem. Mas aqui é preciso cuidado para discernir a que Aristóteles se refere com o termo "matéria". Seu foco não é a matéria enquanto desempenha o papel de matéria, mas a coisa que desempenha o papel de matéria enquanto uma coisa que tem sua própria natureza. Por exemplo, Aristóteles visa o elemento terra enquanto terra, dotado de sua própria natureza. Apenas quando se corrompe a substância é que a matéria (isto é, a coisa que recebe o título de matéria nessa correlação com a substância) vem a ser efetivamente o que ela é, por exemplo: o elemento terra vem a ser efetivamente terra apenas quando se dissolve a substância composta da qual ele era matéria (antes, na mistura que compõe a substância, a terra subsistia por suas capacidades, cf. Geração e Corrupção 327b22-31 e os comentários em Joachim [1926], p. 179-81, e Williams, [1982] p. 144). É por isso que Aristóteles diz que "em efetividade, [a parte e a matéria] são posteriores [ao todo e à substância]" - no sentido de que, quando a substância existe efetivamente, o elemento terra não está presente na substância em sua efetividade, mas pela sua potência. (Se essa estória é correta, o tipo de prioridade identificado em 1019a6-11 não é fundamentalmente diverso do tipo identificado em 1019a12-14.)

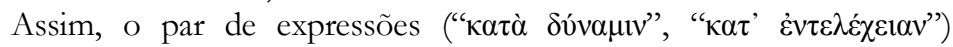
parece aplicado a coisas distintas em um mesmo instante $t$. se $t$ for tomado como o tempo em que a substância composta existe efetivamente, então, nesse mesmo tempo $t$, o elemento terra não existe efetivamente, mas apenas por sua capacidade ou potência. Por outro lado, se $t$ for tomado como o tempo em que o elemento terra existe efetivamente, então, nesse mesmo tempo $t$, a substância composta não existe efetivamente, mas apenas potencialmente.

Se isso é assim, o advérbio " $\alpha \lambda \lambda \omega \varsigma$ " ("de modos diversos", 1019a6) tem por escopo de aplicação as coisas que são, respectivamente, anteriores pela capacidade e anteriores em efetividade. A outra opção seria tomar o advérbio como introduzindo um contraste entre o tipo de prioridade que cabe à substância enquanto subjacente e o tipo de prioridade assinalado pelo par de

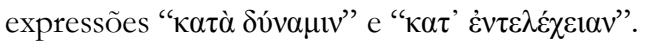

1019a12: "de acordo com essas": qual é o referente do pronome

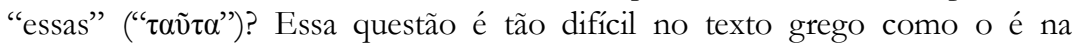
tradução em Português, e por isso não facilitei a vida do leitor. As opções são "as coisas que são anteriores pela classificação de Platão" (que me parece a 
opção mais plausível) e "as coisas que são anteriores pela capacidade e pela efetividade".

\section{Capítulo 12}

Este capítulo deve ser comparado com Metafisica IX.1-5 e Da Interpretação 13-14 (para os sentidos de "possível" etc.).

1019a15: "capacidade" me parece a tradução mais razoável para essas

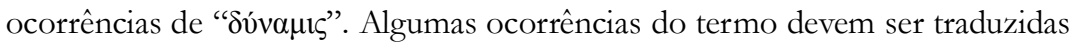
por "poder" (cf. 1018b22-23), outras por "força", outras, talvez, por "potência" (que é a opção mais tradicional), mas o termo "capacidade" é o que melhor capta o núcleo central de acepções do termo grego. Pode haver alguma dúvida (muito bem justificada) sobre a conveniência de se traduzir por

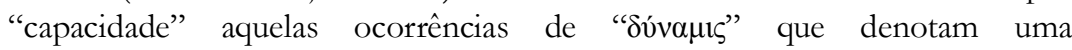
suscetibilidade ou disposição passiva (1019a20-23). De fato, neste caso, o

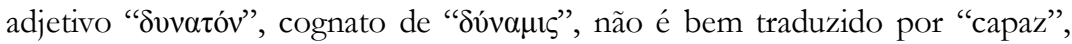
mas por "passível" ou "suscetível" (cf. notas a 1019a21-22). No entanto, preservei "capacidade" para ambos os lados do contraste que Aristóteles propõe em 1019a19-20 (entre capacidades ativas propriamente ditas e disposições passivas). O açúcar tem a propriedade de ser solúvel em líquidos etc. e, por isso, dizemos (na língua ordinária) que ele é suscetivel de ser dissolvido ou passivel de ser dissolvido, mas não dizemos que ele é capaz de ser dissolvido. No entanto, soa mais aceitável dizer que o princípio (isto é, a propriedade disposicional) que o açúcar tem de ser solúvel é uma certa capacidade que o açúcar tem (talvez similar à capacidade que um porta-malas tem).

Para exame meticuloso das noções de capacidade (ativa), suscetibilidade, aptidão passiva etc. ver recente estudo em Beere [2009].

1019a18: "mas não se encontra nele enquanto ele é aquilo que é curado": cf. Física II.1, 192b23-27. Ver Beere [2009], p. 42, Angioni [2009], p. 203-6.

1019a21-22: "dizemos que aquilo que a sofre é passivel de ser

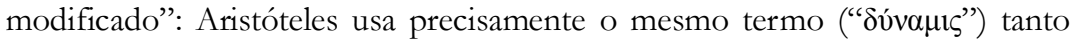
para capacidade ativas como também para suscetibilidades ou disposições passivas, assim como usa o mesmo adjetivo (“'vvvatóv") para se referir aos itens concretos que possuem sejam as capacidades, sejam as disposições passivas, como é o caso nesta sentença. Outro modo de traduzi-la seria: "dizemo-lo suscetivel de se modificar". Uma tradução supostamente literal, como "dizemolo capaz de se modificar", não é viável, pois "se modificar" soa como reflexivo, não como passivo, e (mais importante) o adjetivo "capaz" em Português parece ter-se consolidado no sentido ativo. De fato, "dizemo-lo capaz de ser modificado" soa bem estranho. Por outro lado, os gaúchos dizem "é bem 
capaz!" como uma exclamação equivalente a "Improvável! Implausível! Nem pensar!", mas neste caso o adjetivo "capaz" não se aplica a pessoas, substâncias, coisas etc., mas a fatos ou proposições, de modo similar ao adjetivo "possível".

1019a23-26: "denomina-se capacidade a capacidade de executar bem uma certa coisa etc.": esta passagem é elucidativa. Ela mostra que Aristóteles era sensível ao fenômeno lingüístico pelo qual dizemos que Fulano não sabe fazer $F$ se Fulano faz F mal ou de um modo medíocre. Por exemplo, dizemos que o surfista calhorda não surfa nada, se ele surfa mal; ou dizemos que Pelé não jogou nada, se ele jogou mal; também podemos dizer que o surfista calhorda não sabe surfar, se ele surfa mal. Em grego, em vez de verbo equivalente a saber, usa-

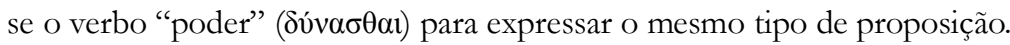

Em muitos casos, a capacidade de executar bem uma determinada tarefa F é identificada como a virtude (àpetí) para F, como em Ethica Nicomachea 1106a15-21. Dado que a mera capacidade, no mais alto grau de generalidade, é o gênero da hexis, a qual, por sua vez, é o gênero da virtude, segue-se que o uso do termo "capacidade" identificado em 1019a23-26 é um daqueles casos em que o termo que designa o gênero é usado para designar um de seus casos

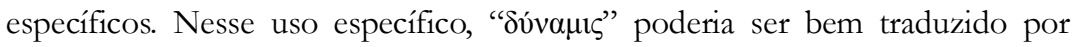
"habilidade", "aptidão", "habilitação" ou "competência". Ver Beere [2009], p. 47.

1019a26-32: "denominam-se capacidades as disposições pelas quais as coisas são, em geral, impassíveis etc.”: o termo que Aristóteles mais utiliza para designar propriedades disposicionais (como fragilidade, solubilidade e

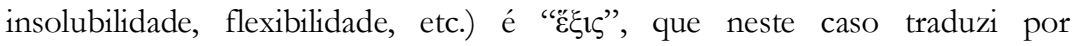
"disposição". No entanto, Aristóteles designa propriedades disposicionais

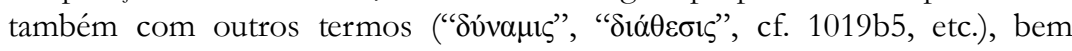
como usa o termo " $\varepsilon \xi \iota \zeta$ " de modo mais estrito, para designar (em vez de disposições ou poderes que as coisas naturalmente têm) capacidades adquiridas e consolidadas pelo exercício. Cf. EN 1103b22-23, 31; 1104b19.

Para exame dessa passagem, ver Beere [2009], p. 45-6.

1019a31-32: "por sua capacidade, isto é, por terem certos poderes e

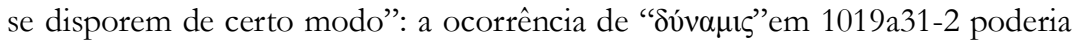
eventualmente ser traduzida por "poder", mas usei o termo "poder" na

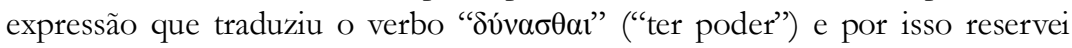

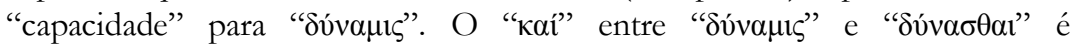
claramente epexegético.

1019a35-b1: "se denominará passivel se outra coisa possuir tal capacidade em relação a ele": uma tradução igualmente razoável seria esta: "se denominará suscetivel de algo se outra coisa possuir tal capacidade em relação a 
ele". Ver nota a 1019a21-22. A razão para manter minha opção é que reservei a expressão "suscetível de $F$ " para certas ocorrências do particípio presente,

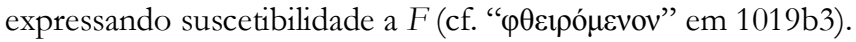

1019b10-11: "algo se denomina forte porque nenhuma outra coisa (...) possui capacidade de destruí-lo": dificilmente soaria bem em Português dizer que "algo se denomina capaz porque nenhuma coisa possui capacidade de destruí-lo". Outras opções razoáveis para traduzir este uso do adjetivo

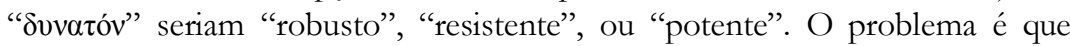
"potente" não capta tão bem o ponto, e as outras opções não preservam tão bem a relação com noções que se organizam em torno do conceito de

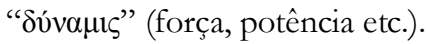

1019b10: "caso contrário, se dará por homonímia": segui o texto de Ross e, portanto, aceitei a transposição que ele propõe para essas palavras, que soam deslocadas em suas ocorrências nos códices. Cf. Ross [1924], p. 321.

1019b11-15: “ou porque ocorrem apropriadamente etc.”: cf. 1019a2326. Em 1019a23-26, o ponto de Aristóteles dizia respeito às capacidades ativas de fazer algo específico (falar, andar etc.). Aqui, o ponto de Aristóteles diz respeito às capacidades entendidas como disposições passivas pelas quais (por meio de um agente externo) se produz um resultado específico. A expressão "apta a soar" traduz " $\delta v ́ v \alpha \sigma \theta \alpha \iota$ l $\varphi \theta \dot{\varepsilon} \gamma \gamma \varepsilon \sigma \theta \alpha \imath "$. Tradução supostamente literal ("pode soar" , "tem o poder de soar") não captaria o ponto. Na sentença " "ìेv

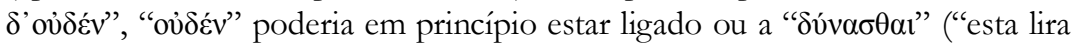
não pode nada") ou a " $\varphi \theta \dot{\varepsilon} \gamma \gamma \varepsilon \sigma \theta \alpha$ ”" ("esta lira não soa nada"). No entanto, creio que o contexto favorece a segunda opção. Diante de uma faca de qualidade medíocre, dizemos "esta faca não corta nada" (em vez de dizer "esta faca não pode nada"), assim como dizemos que o surfista calhorda não surfa nada. Do mesmo modo, em grego, o contraste é entre " $\varphi \theta \varepsilon ́ \gamma \gamma \varepsilon \sigma \theta \alpha 1$ ov̉ośv" e

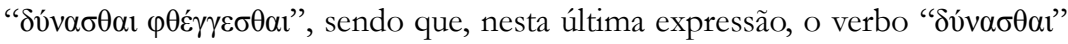
é usado para assinalar aptidão, superioridade ou excelência (como em 1019a25).

1019b22ss.: "outras se denominam de outro modo, qual seja, o possível e o impossível": neste caso, não apenas é indesejável, como também enganador, ou simplesmente incorreto, tentar manter os termos "capaz" e

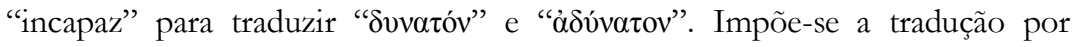
"possível e "impossível". Aristóteles tem plena consciência da diferença entre

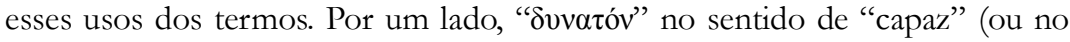
sentido passivo de "suscetível/ passível de") se aplica a coisas (substâncias, artefatos, elementos materiais etc.) em atenção a propriedades disposicionais pelas quais elas produzem certos resultados em interações com outras. Por

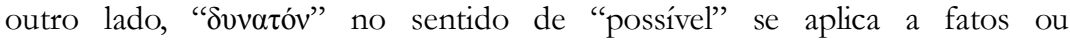


proposições.

1019b25-26: “porque é de tal modo falso que não apenas seu contrário é verdadeiro - mas é também necessário [que seja incomensurável]":

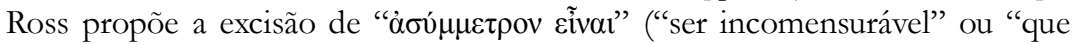
seja incomensurável"). No entanto, o trecho pode ser preservado, sob o baixo custo de haver uma pequena irregularidade na sintaxe, a qual não surpreende, em comparação com outros anacolutos evidentes nos textos de Aristóteles. ${ }^{2}$

1019b27-29: “o contrário dele, isto é, o 'possível', se dá quando um dos contrários não é necessariamente falso": o trecho é bem sutil e elucidativo a respeito das práticas lingüísticas de Aristóteles. É imprescindível empregar

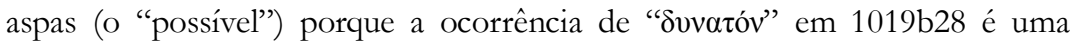
menção, não um uso do termo. Aristóteles tem em mente uma sentença como esta: “o 'possível' é o contrário do 'impossível”". Suponha que, em dado contexto, o termo "possível" seja empregado para designar a proposição Sócrates está sentado. Por sua vez, esta proposição, Sócrates está sentado, é contrária à proposição Sócrates não está sentado. Dado que a proposição Sócrates está sentado é dita possível, se poderia dizer que o contrário do possível é a proposição Sócrates não está sentado - porque esta proposição é contrária a Sócrates está sentado, a qual é possível. No entanto, Sócrates não está sentado é uma proposição igualmente possível. Seria falso, portanto, dizer que essa proposição (Sócrates não está sentado), por ser contrária a uma proposição possível, é impossível.

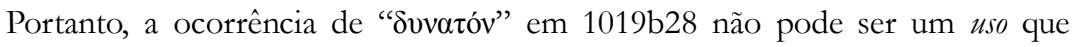
remetesse a uma proposição concreta, mas é uma menção: Aristóteles visa o conceito designado pelo termo "possível", que é contrário ao conceito designado pelo termo "impossível".

Nota que, na mesma linha (1019b28), há duas ocorrências do termo "Ėvavtíov". A primeira, como acabamos de explicar, remete ao conceito de impossivvel, que é contrário ao conceito de possível, e mostra que a ocorrência do

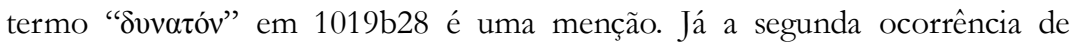
"Ẻvavtíov" é um uso do termo para remeter a uma das proposições concretas que constituem um par de contrários, por exemplo, Sócrates não está sentado.

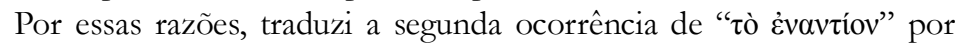
"um dos contrários", para deixar claro que a expressão é usada para se referir a uma das proposições concretas que constituem o par de contrários. Outras opções mais literais engendrariam enigmas ou non-sense, por exemplo: “o contrário dele, isto é, o possível, se dá quando seu contrário não é necessariamente falso" (que poderia ser entendida como equivalente desta: "o

${ }^{2}$ Agradeço a Michel Crubellier por me chamar atenção para esse ponto. 
contrário dele [do impossível], isto é, o possível, se dá quando seu contrário [o impossível] não é necessariamente falso". ${ }^{3}$

Para exame das dificuldades, ver Kirwan [1993], p. 159.

1019b33-34: "a 'potência' na geometria se diz por metáfora": usei "potência" porque o termo está consagrado em Português para as potências na

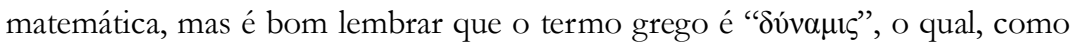
Aristóteles deixa claro, é usado por metáfora neste caso (pois é evidente que, em sentido estrito, números e figuras não são capazes de fažer algo do mesmo modo que as coisas materiais). Para outra interpretação, ver Beere [2009], p. 40.

1020a2-4: "se denominam passiveis [...] ou fortes, [...] ou aptas": em princípio, a tradução deve evitar o uso de disjunções para traduzir uma mesma expressão em Grego. Neste caso, no entanto, impõe-se alguma solução para salvar a inteligibilidade do texto em Português. Nesta passagem, Aristóteles

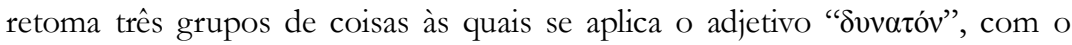
propósito de ressaltar que todas elas fazem referência ao primeiro tipo de capacidade, que é aquela cuja definição foi dada na primeira sentença do capítulo (1019a15-16) e é retomada na sentença final (1020a4-6). Ora, para cada um desses três grupos de coisas, usamos um termo diferente em

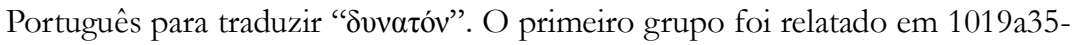
b10: são as coisas ditas passiveis de $X$, que dependem de um agente externo que tem a capacidade ativa de fazer $X$ em tal coisa. $O$ segundo grupo foi apresentado em 1019b10-11: são as coisas ditas impassiveis de serem destruídas, as quais também se referem a um agente externo que, neste caso, não tem a capacidade destrui-las. A tradução que adotei para o adjetivo "Svvatóv" aplicada ao segundo grupo foi "forte". Finalmente, o terceiro grupo foi reportado em 1019b11-15: são as coisas ditas aptas a X, que dependem de um agente externo que as usa para fazer $X$ (como a lira). Assim, em atenção às

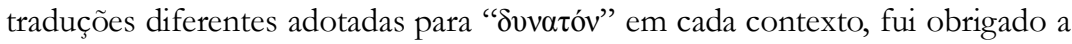
usar, neste parágrafo final recapitulativo, a expressão disjuntiva "se denominam passiveis $[\ldots]$ ou fortes, $[\ldots]$ ou aptas".

(Talvez o terceiro grupo se reporte antes às coisas que "não são facilmente modificáveis para pior", em 1019a27-28, que dependem de um agente externo que tem uma capacidade de fazer $X$ sobre elas de um modo determinado. No entanto, esse ponto não interfere no princípio de tradução aqui adotado: eu teria que usar uma expressão disjuntiva de todo modo).

1020a4-6: "a definição dominante é a do primeiro tipo de capacidade

${ }^{3}$ Agradeço Michel Crubellier por observações que me auxiliaram a formular este ponto com mais clareza. 


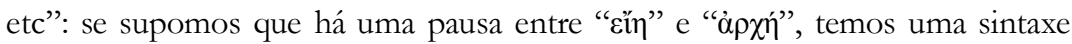
que ressalta, como conclusão do capítulo, que a definição do primeiro tipo de capacidade é que é a dominante, no sentido de ser a definição principal, a partir da qual se articulam as demais; em seguida, o enunciado da definição ela mesma ("princípio de mudança em outra coisa ou na própria coisa enquanto é outra") é como que uma mera aposição, ou explicitação, ou lembrete sobre seu conteúdo.

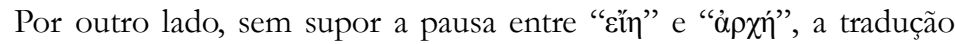
seria antes a seguinte: "a definição dominante do primeiro tipo de capacidade é esta, 'princípio de mudança em outra coisa ou na própria coisa enquanto é outra"'.

$\mathrm{Eu}$ prefiro a primeira opção, que resulta em um andamento argumentativo mais conectado e interessante. Aristóteles já utilizou a definição da capacidade primeira (ou primeiro tipo de capacidade) várias vezes no capítulo. Não haveria nenhuma novidade em dizer ou ressaltar, ao final do capítulo, que este é o conteúdo da definição etc. Por outro lado, é uma boa conclusão para o capítulo ressaltar que a definição do primeiro tipo de capacidade é, de fato, a definição mais importante, em torno da qual as demais se articulam (sobretudo após a menção dos casos supostamente recalcitrantes, como o par possível/ impossível e as potências geométricas).

\section{Capítulo 13}

Este capítulo deve ser comparado com Categorias 6, também dedicado à quantidade. Há significativo acordo entre o conteúdo de ambos os textos. As diferenças mais relevantes estão devidamente ressaltadas em Ross [1924], p. 323.

1020a7: "denomina-se de certa quantidade": usei o itálico para destacar

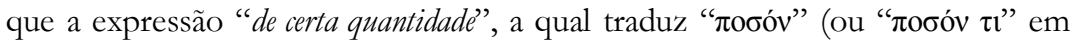
linhas seguintes), funciona como uma variável livre ou um placeholder, e sintaticamente é um adjetivo que se aplica a substantivos ou expressões nominais. Na forma interrogativa, a expressão deve ser traduzida assim: "de que quantidade é X?”, onde "quantidade” pode ser substituído, de acordo com o contexto, por "tamanho", "comprimento", "largura", "volume", etc.

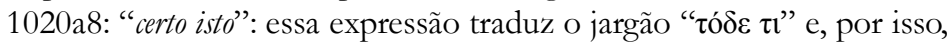
foi posta em itálico. Certa tradição interpretativa insistiu e insiste em tomar a

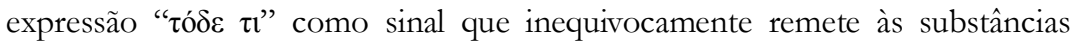
individuais (isto é, indivíduos como Sócrates e Bucéfalo, que contam como substâncias primeiras de acordo com a nomenclatura das Categorias). Esta ocorrência da expressão é um bom contra-exemplo que falsifica essa interpretação tradicional. Neste caso, a expressão não remete nem sequer para 
um item na categoria da substância, muito menos para uma substância primeira.

1020a9-10: "se for suscetível de ser medido, é uma grandeza": o termo " $\mu \varepsilon ́ \gamma \varepsilon \theta$ o $\varsigma$ " designa neste caso as grandezas contínuas. Para outra ocorrência da expressão, ver 1021b23.

1020a17-20: "umas o são por essência (...), outras são características e condições desse tipo de essência": o termo "oủ $\sigma i ́ \alpha$ ” ocorre duas vezes, em 1020a18 e 1020a20. Na segunda ocorrência, seria tentador traduzi-lo por "substância", pois parece claro que o termo indica o substrato das características e modificações quantitativas, e Aristóteles admite que entidades matemáticas possam ser denominadas, sob certas restrições e sob o devido controle, como "substâncias" (cf. Segundos Analíticos 87a36), embora, em última análise, não sejam substâncias (cf. Metafísica XIII). No entanto, parece claro que características como o longo e o curto etc. são modificações do modo de ser que é típico das entidades matemáticas, isto é, são modificações das essências desse tipo, quais sejam, as essências que determinam as entidades matemáticas enquanto tais.

1020a19: “pois 'certa quantidade' está presente na definição que define o que ela é": Aristóteles parece usar a expressão " $\pi$ oбóv $\tau \imath$ " como placeholder para expressões que estariam presentes na definição que formula a essência da linha. No entanto, não é muito claro o que ele quer dizer, pois não

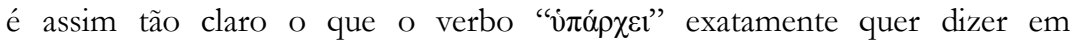

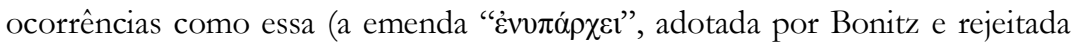
por Ross, não viria ajudar em nada). O verbo pode indicar que a expressão "лобóv $\tau$ " ou alguma de suas especificações está imediatamente presente na definição da linha etc., ou pode indicar que a expressão “ $\pi$ oбóv $\tau$ ”” ou alguma de suas especificações está implicitamente presente na definição da linha porque pode ser obtida pela análise de algum de seus componentes. Por exemplo: de acordo com os Platônicos pitagorizantes reportados em Metafísica Z.10-11 e H.3, sobretudo 1043a33-34, a linha deve ser definida como "Dois em

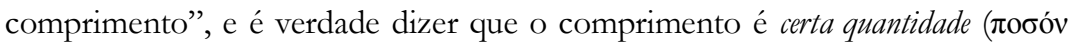
$\tau i)$.

1020a19: "características e condições”: isso traduz os termos " $\pi \alpha ́ \theta \eta ”$ e

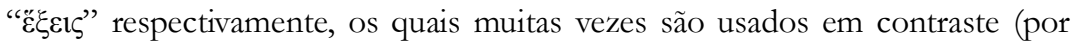
exemplo, em Ethica Nicomachea II.5). Nesta passagem, contudo, esses termos parecem não codificar nenhuma distinção relevante; antes, parecem apenas denominações opcionais dos mesmos itens.

1020a24-25: "são, em si mesmas, características da quantidade, o grande e o pequeno": a rigor, seria plausível traduzir de outro modo: "são características da quantidade, tomada em si mesma”. A quantidade é tomada 
em si mesma quando se lhe atribuem as características em questão (cf. 1019a1, 1022a30-31), e se poderia dizer que é por essa razão que o escopo da expressão "em si mesmo" ( $\kappa \theta^{\prime}$ ' avió) se transfere para as características atribuídas ao sujeito tomado em si mesmo, de modo que a expressão parece funcionar como um adjetivo de "características" (na tradição ingelsa, por exemplo, fala-se de per se properties). No entanto, essas questões de escopo são controversas. Pode-se julgar que as características e os atributos têm, também, suas próprias essências (cf. Segundos Analíticos 90a31-34), e faz parte dessas essências a propriedade de ser atribuído aos sujeitos apropriados. Por isso, é pertinente dizer que "são, em si mesmas, características da quantidade, o grande e o pequeno": pois a essência do atributo grande, por exemplo, envolve o ser atribuído ao sujeito apropriado a que se atribui, a quantidade.

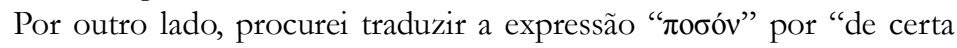
quantidade" (em vez de "quantidade") sempre que possível, pelas razões assinaladas no comentário a 1020a7. No entanto, nesta ocorrência em 1020a25, traduzi por "quantidade" para simplificar a sintaxe, que é complicada e envolve muitas outras dificuldades adicionais (aquelas que, por exemplo, me obrigaram a distribuir em parênteses distintos as expressões "de coisas em si mesmas" e "de coisas que assim se dizem umas em relação às outras").

1020a30: traduzi esta ocorrência de " $\pi \dot{\alpha} \theta \eta$ ” por "propriedades" (em vez de "características" ou "modificações") devido ao contexto.

\section{Capítulo 14}

Este capítulo deve ser comparado com Categorias 8, também dedicado à qualidade. As diferenças são mais discrepantes que no caso do capítulo anterior.

1020a33: "denomina-se de certa qualidade": usei o itálico para destacar

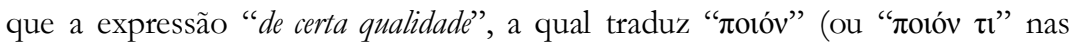
linhas seguintes), funciona como uma variável livre ou um placeholder. A reflexão de Aristóteles parte de sentenças ordinárias, como "ser humano é um animal bípede", "cavalo é um animal quadrúpede", e "de certo tipo" (" $\pi$ otóv") é usado para demarcar o que há em comum entre as diferenças bípede e quadrúpede, que qualificam o tipo de animal que cada respectivo sujeito é. O termo " $\pi$ oıóv" substitui os termos que introduzem as diferenças e desempenha a mesma função sintática que eles. Por isso, é melhor seguir Bonitz e Ross e

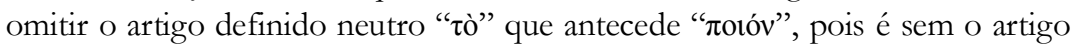
que "Totóv" funciona exatamente do modo como acabei de descrever. Uma opção aceitável seria reter o artigo e entendê-lo como introduzindo menção (em vez de uso) de " $\pi$ otóv", como ocorre na primeira sentença de alguns capítulos do livro V (7, 18 e 23), bem como em 1020b14 e 1020b23-24. A 
construção ficaria irregular, mas é plausível especular que a irregularidade seja

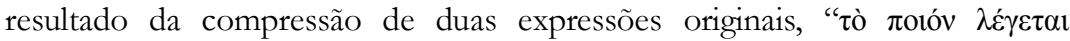

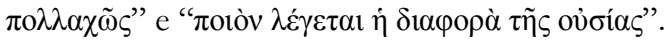

1020a33: esta ocorrência do termo "ov̉oía" é mais bem traduzida pelo termo "essência" (em vez de "substância"), como muitas outras. Logo mais abaixo (1020b9), "ov̉øía" é usado de tal modo que "substância" é mais conveniente. A mudança de uso do mesmo termo em um curto intervalo de linhas é muito comum em Aristóteles. Minha posição detalhada sobre o problema dos usos de "oủoía" está em Angioni [2008], p. 23ss.

1020b5-6: "tantas vezes tanto", "tantas vezes tantas vezes tanto": preferi ser bem literal e deixar claro o aspecto cru do texto grego, mas é evidente que "tantas vezes tanto" equivale a "X.Y" ("X vezes Y"), e "tantas vezes tantas vezes tanto" equivale a "X.Y.Z".

1020b9: nesta linha, o termo "oủó́a" é mais bem traduzido por "substância" (em vez de "essência"). Ver nota a 1020a33. Ver logo em seguida as ocorrências nas linhas $1020 \mathrm{~b} 15$ e 16, nas quais a dificuldade é mais premente.

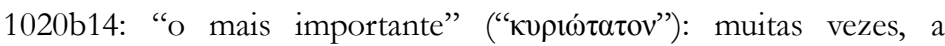

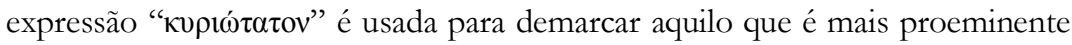
no uso ordinário da língua. Algumas vezes, porém, a mesma expressão é usada para demarcar o uso ao qual Aristóteles confere algum tipo de prioridade, como ocorre neste caso: o modo mais importante em que a expressão "de certa qualidade" é usada é o modo que expressa a diferença da essência, a qual em seguida é associada ao primeiro tipo de qualidade.

1020b15-17: "é uma diferença de essências, mas [de essências] de coisas que não são suscetíveis de movimento": novamente, as duas ocorrências do termo "ov̉oía" são mais bem traduzidas por "essência" (como em 1020a33,

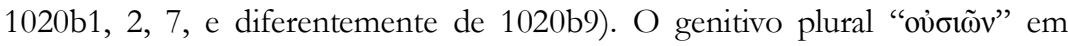

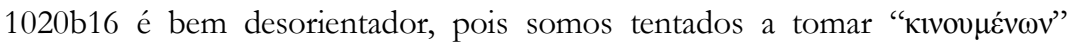
(logo em seguida) como se fosse um predicativo de "ov̉øī̄v" (e, se fosse um predicativo, "oủ бía" deveria ser tomado no sentido de substância, pois são as substâncias, não as essências, que são suscetíveis de movimento). No entanto, o neutro plural na expressão "kıvov́ $\mu \varepsilon v \alpha$ " (usada na seqüência) deixa claro que

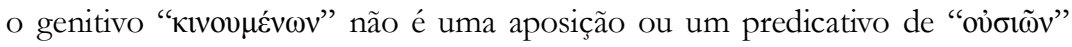

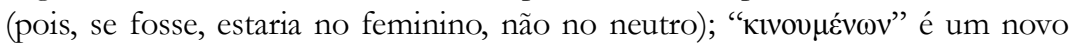
genitivo, com função subjetiva, que depende de "oủoī̃v", identificando assim os itens que têm essência.

1020b17-18: "outro tipo de qualidade são as características das coisas suscetíveis de movimento etc.": confesso que não entendi o relato de Ross [1924], p. 326-7, a respeito da suposta dificuldade sintática desta sentença. No 


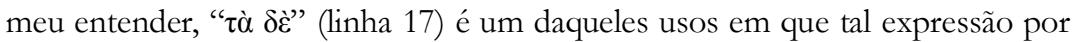
si só tem a força de "outras coisas, por sua vez". Neste caso, a expressão

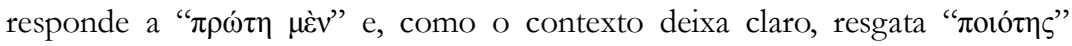

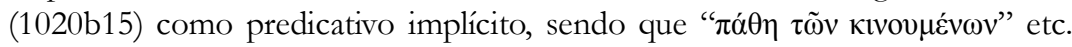
são os predicados da sentença: "outros itens, por sua vez, [sc. que contam como qualidades] são as características das coisas suscetíveis de movimento etc.".

1020b18-19: “a excelência e o vício são uma parte dessas características": traduzi " $\pi \alpha \theta \eta \dot{\mu} \mu \alpha \alpha$ ” por "características", em vez de opções supostamente literais, como "afecções". É no mínimo divertido ver Aristóteles usar essa nomenclatura e, por outro lado, se empenhar em um argumento (em Ethica Nicomachea II.5) que estabelece que a excelência do caráter não é um $\pi \dot{\alpha} \theta$ os.

1020b21-23: "bom é aquilo que é capaz de se mover ou estar em atividade de tal e tal modo etc.”: essa observação está plenamente de acordo com uma tese que é mais bem especificada por Aristóteles ao caracterizar a noção geral de virtude ou excelência em Ethica Nicomachea II.6, 1006a15-21: toda excelência torna bom seu possuidor, isto é, torna boa sua atividade própria.

1020b23-24: “de certa qualidade' quer dizer bom ou man sobretudo no caso das coisas animadas etc.": neste caso, o termo que traduzi entre aspas é objeto de menção (não de uso). Para uso de " $\pi$ otóv" etc. para denotar qualidades morais, cf. Ethica Nicomachea 1103b22, 31. Alexandre (401.21-23) parece ter lido a sentença de modo diferente, como se "tò $\pi$ otóv" fosse complemento do

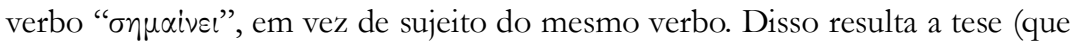
Alexandre parece atribuir a Aristóteles) de que bom indica algo na categoria da qualidade apenas quando se aplica a coisas animadas (dotadas de propósito), ao passo que, aplicado a coisas inanimadas, bom indicaria um item em alguma das outras categorias. Não vejo nenhuma evidência para a tese de Alexandre, a qual deriva de uma leitura da sentença que julgo sintaticamente infeliz. A tese de Aristóteles é simples e clara: a expressão "de certa qualidade", que pode querer dizer bom ou man também em outros registros, quer dizer bom on man sobretudo quando aplicada a seres dotados de propósito etc. Dizer que tal número é par implica dizer que tal número é de tal e tal qualidade (pois ser par é um caso específico de ser de tal e tal qualidade), mas isso não quer dizer que tal número é bom ou ruim. Por outro lado, dizer que esta faca é afiada envolve dizer que ela é de tal e tal qualidade e, neste caso, isso quer dizer que ela é boa (para cortar). No entanto, é sobretudo quando se aplica a seres dotados de propósito que a expressão de tal qualidade quer dizer que alguém é bom ou ruim (sem mais, isto é, do ponto de vista moral). 
1020b24-25: "possuem propósitos": o texto tem "prohairesis" no singular, mas traduzir literalmente pelo singular ("possuem propósito") seria inconveniente pelo risco de sugerir erroneamente que Aristóteles quer dizer que as coisas em questão possuem um desígnio, uma finalidade extrínseca. Em Português, sentenças equivalentes ao que Aristóteles quer dizer são enunciadas com o plural. Como um paralelo elucidativo, veja a diferença entre "Brasileiros têm preferências" (isto é, Brasileiros em geral preferem o verão ao inverno, preferem o sol à chuva etc.) e "Brasileiros têm preferência" (isto é, Brasileiros podem passar à frente dos europeus na fila da alfândega etc.).

\section{Capítulo 15}

Este capítulo deve ser comparado com Categorias 7, texto no qual o assunto em questão recebe o tratamento mais pormenorizado no Corpus Aristotelicum.

1020b16-17: “o que é $x$-vezes em relação ao que é uma $x$-parte [dele]": literalmente, trata-se da relação entre X.1 e X.1/X, ou simplesmente, entre X.1 e 1, a qual é uma generalização dos casos anteriores, nos quais há um número determinado no lugar de " $\mathrm{X}$ " e há denominações exatas já estabelecidas na língua (dobro/metade, triplo/terça-parte etc.). Para detalhes sobre a classificação que Aristóteles faz dos relativos numéricos, ver Heath [1949], p. 209-211.

1020b29: "aquilo que esquenta em relação ao que é suscetível de ser esquentado": outra opção de tradução seria "o aquecedor em relação ao aquecível”, ou "o esquentador em relação ao esquentável”. A vantagem seria evitar as locuções com orações relativas, que deixam o texto menos fluente. No entanto, procurei evitar essas soluções quando a palavra em questão se sedimentou no Português com um sentido determinado ("aquecedor") ou quando soa inusual ("esquentador").

1020b32-1021a4: “X.y [“muitas vezes tal número”] é em relação a um número, mas não é determinado": todas as expressões que introduzi com auxílio das variáveis (" $x$ " etc.) traduzem uma única palavra grega, por exemplo, " $x . y$ " [ou "muitas vezes tal número"] traduz o termo " $\pi 0 \lambda \lambda \alpha \pi \lambda \alpha \dot{\sigma} \sigma 10 v "$, e assim por diante.

Aristóteles compara os termos " $x . y$ " e " $x .2$ " (i.e., dobro): o que ele ressalta é que, em certos casos, o parâmetro em relação ao qual um dado número é relativo é determinado, como no caso do dobro ( $x$.2): o parâmetro, que é determinado, é o número 2. Já para " $x . y$ ”, o parâmetro é algum número (isto é, $y$ ), que não é determinado.

É interessante observar que a indeterminação dos parâmetros é assinalada pelo advérbio " $\dot{\alpha} \pi \lambda \tilde{\omega} \zeta$ " ("sem mais"). Esse advérbio freqüentemente 
expressa indeterminação - e é o contexto que delimita se a indeterminação é desejável (por exemplo, em contextos em que se delimita um objeto por abstração e seleção do que há de comum em todas suas múltiplas especificações, cf. Metafísica 1026a33; Ética a Nicômaco 1147b20) ou prejudicial (por exemplo, em contextos em que a especificação de detalhes é requisitada, cf. Geração e Corrupção 333b22; Física 186a24; De Anima 417a22, 426a26; Ref. Sofisticas 176a4-5; $181 \mathrm{~b} 5$ etc.). Cf. Ref. Sofísticas 168b11-16. Em alguns contextos do primeiro tipo, "á$\pi \lambda \tilde{\omega} \varsigma$ " é usado para demarcar um conceito depurado de todas suas especificações (ou contaminações) contextuais (cf. Tópicos 137b2833ss.; Metafisica 1052a19). Em outros casos, "d் $\pi \lambda \tilde{\omega} \varsigma$ ” é usado para identificar o tipo mais importante ou mais acabado de algo (como em Segundos Analíticos 71b9-12, aplicado a uma forma superior de conhecimento; ou em 1018a2, para identificar os sujeitos de atribuição estritamente apropriados a predicados acidentais; cf. Tópicos 116a21; Metafísica 1028a31). A rigor, é esse uso de "d்́ $\lambda \tilde{\omega} \zeta "$ que é o mais conhecido (cf. Metafísica 1028a31). Muitos intérpretes, porém, se enganam em dizer que esse uso é o mais prominente nos textos de Aristóteles. O próprio Aristóteles tem plena consciência de que o advérbio é usado de muitos modos (cf. Geração e Corrupção 317b5-7, em que dois usos distintos do advérbio geram resultados bem diferentes. Para discussão detalhada, ver Joachim [1926], p. 90 e Williams [1982], p. 81-3).

1021a5-6: “o que não é comensurado não se afirma como um número": Aristóteles quer dizer que, no caso (por exemplo) de x.y (" $\pi \circ \lambda \lambda \alpha \pi \lambda \dot{\alpha} \sigma ı v ")$, bem como no caso da relação entre excedente e excedido ( $x$ $+y, x)$, o parâmetro $y$ não é comensurado, isto é, não é determinado, não equivale a nenhum número determinado (não equivale, por exemplo, ao " 2 ", que é o parâmetro determinado em relação ao qual algo é dito dobro). Para exame dos problemas presentes na classificação de Aristóteles, ver Ross [1924], p. 328-9 e Kirwan [1993], p. 164.

1021a13-14: "se denominam 'em relação a algo' conforme ao número": Aristóteles quer dizer que o "mesmo" expressa uma relação conforme ao número de essências (dizer que X é o mesmo que $\mathrm{Y}$ consiste em dizer que há apenas uma essência para X e Y); o "igual” expressa uma relação conforme ao número de quantidades (dizer que $\mathrm{X}$ é igual a $\mathrm{Y}$ consiste em dizer que $\mathrm{X}$ e Y são de mesma quantidade) etc.

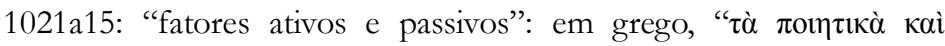
$\pi \alpha \theta \eta \tau \leftarrow \kappa \alpha ́$ ", expressões que, no mais alto grau de generalidade, podem ser traduzidas como "coisas que produzem" e "coisas que sofrem/padecem".

1021a16-19: Aristóteles observa que as correlações apropriadas devem ter ambos os correlatos obedecendo aos mesmos parâmetros. Assim, o que aquece (isto é, o que é capaz de aquecer) e o que é aquecível são os 
correlatos apropriados quanto ao parâmetro da dynamis (capacidade ativa/ suscetibilidade passiva); o que está esquentando e o que está sendo esquentado são os correlatos apropriados quanto ao parâmetro da efetividade. Para observação semelhante (quanto aos relata de relações causais), cf. Física II.3, 195b25-28. Em 1021a21-23, Aristóteles acrescenta ainda o fator temporal na correlação: ambos os correlatos devem ser formulados no mesmo tempo (presente, passado ou futuro). Observação semelhante pode ser encontrada em Segundos Analíticos II.12, 95a24-39.

1021a26-30: "são em relação a algo porque aquilo que elas

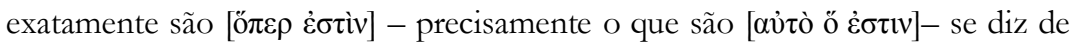
uma outra coisa": Aristóteles tece considerações mais complexas sobre a semântica e a ontologia dos relativos. Alguns relativos - os que assim se dizem conforme ao número e à capacidade - são de tal modo que a relação com seu correlativo apropriado é por assim dizer encapsulada na denominação que lhes cabe (por exemplo, "dobro" por si só, para quem tem a competência lingüística adequada, quer dizer "dobro em relação ao que é sua metade", "cortante" quer dizer "capaz de fazer tal e tal ação naquilo que é suscetível de ser cortado" etc.). Esse modo de denominação está fundamentado no modo de ser dos itens identificados como relativos e correlativos. Aquilo que um relativo precisamente é ele mesmo é em relaşão a outra coisa, e é por isso que o termo que o denomina é usado do modo como é usado.

Há um contraste com outros tipos de relativo, os quais seriam classificados como relativos não porque aquilo que precisamente são envolve a relação com outra coisa, mas porque outra coisa se diz relativa a eles. Por exemplo, o fato de Sócrates estar sentado é dito cognoscível. No entanto, o fato de Sócrates estar sentado é o fato que ele é independentemente de haver algum conhecimento dele (cf. Metafísica 1010b31-1011a2, 1051b6-9). Contudo, como pode haver um episódio cognitivo que se associa estritamente a esse fato (isto é, como se pode vir a conhecer que Sócrates está sentado), esse fato é denominado como congnoscível, mas porque outra coisa (i.e., um episódio de cognição) se diz relativa a ele, não porque aquilo que ele exatamente é em si mesmo seja relativo a tal episódio de cognição.

É claro que, ao defender essa tese (isto é, que o cognoscível é um relativo, mas não porque aquilo que ele exatamente é seja em relação a outra coisa), Aristóteles toma o termo "cognoscível" em seu modo material, isto é, como se reportando àquilo que o termo denota - Aristóteles está falando de um fato (p. ex., Sócrates estar sentado) enquanto ele é tão somente tal fato. Por outro lado, na medida em que tal fato se torna conhecido (ou na medida em que é possível haver conhecimento dele), ele cai sob a rubrica do "cognoscível" e, enquanto cognoscivel, seria correto dizer que ele é cognoscivel 
porque aquilo que ele exatamente é (enquanto cognoscível) se diz com remissão à outra coisa (isto é, ao conhecimento). Aristóteles é, portanto, bem

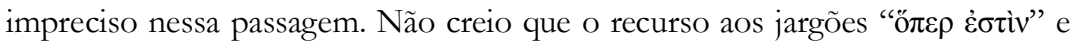

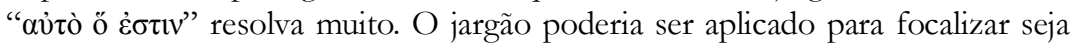
aquilo que o fato de Sócrates estar sentado é em si mesmo, seja aquilo que o fato de Sócrates estar sentado é enquanto cognoscivel.

1021a31: “pensável' quer dizer que há pensamento disso”: temos aqui um caso claro em que Aristóteles menciona um termo ("pensável") para definir o que ele quer dizer (ou o que ele significa).

1021a31-33: “o pensamento não é em relação àquilo de que é pensamento (se fosse, o mesmo item seria mencionado duas vezes)": há algo muito estranho aqui. O trecho 1021 a26-30 explicou que aquilo a que aplicamos o termo "pensável" - por exemplo, o fato de que Sócrates está sentado independe do pensamento para ser precisamente aquilo que ele é em si mesmo. Sócrates estar sentado não precisa ser um correlativo do pensamento para ser o fato que é. Se aplicamos a esse fato o termo "pensável", isso quer dizer que há pensamento desse fato. Agora, em 1021a31-33, temos a impressão de estar diante de um glosa de alguém que não entendeu a passagem anterior: Aristóteles estaria a dizer que o pensamento não é em relação a seu correlativo (quando, a rigor, a lição do trecho precedente é que o pensável não é precisamente aquilo que é em si mesmo em relação a seu correlativo). Para exame meticuloso da dificuldades e da inconsistência da passagem como um todo, ver Kirwan [1993], p. 165-6.

A menção ao psitacismo (“dizer o mesmo duas vezes") logo na seqüência pode dar uma pista para salvar o texto. Aristóteles - como é o caso em outros contextos em que o psitacismo é mencionado - estaria a se referir a dificuldades meramente lingüísticas que alguns teriam desenvolvido de modo erístico. A rigor, a repetição do mesmo duas vezes também ocorreria no caso do dobro e da metade (cf. Refutacõoes Sofísticas 31). Se alguém concede que o termo "dobro" sempre encapsula uma referência à metade (de modo a ser equivalente a "dobro de sua metade"), então, sempre que alguém pronunciar a expressão "dobro da metade", o sofista poderia efetuar a substituição de "dobro" (em "dobro da metade") por "dobro da metade", gerando a frase "dobro da metade da metade" (cf. Fait, [2007] p. 213-4). De modo similar, se alguém concede que "dobro é uma quantidade relativa à metade" e que "metade é uma quantidade relativa ao dobro", o sofista poderia inferir que "dobro é uma quantidade relativa a uma quantidade relativa ao dobro", ou que "metade é uma quantidade relativa a uma quantidade relativa à metade". Traços sofísticos também se fazem presentes na passagem seguinte.

1021a33-b3: "também a visão é visão de algo etc.": neste caso, o 
problema (e o eventual truque sofístico) depende da ambigüidade do genitivo: "de algo", na expressão "visão de algo", pode ser genitivo objetivo (remetendo ao objeto apreendido pela visão) ou subjetivo (remetendo ao sujeito no qual se localiza a capacidade perceptual) (cf. mesmo tipo de problema em Tópicos 125b6-9). É claro que as correlações apropriadas se dão entre as atividades (ou capacidades) e seus objetos. Em suma, é bem obscura a natureza das observações avançadas por Aristóteles neste contexto.

1021b4-6: "se seus gêneros forem desse tipo; por exemplo: a medicina": esta passagem parece remeter a uma tese bem assentada na filosofia de Aristóteles (cf. Categorias 11a23-32). No entanto, a suposta tese (que a ciência é um relativo, embora nenhuma ciência particular - como a medicina ou a ciência das letras - seja um relativo) também é repleta de obscuridades. Em primeiro lugar, não é claro se Aristóteles, ao pretender identificar uma diferença entre medicina (por exemplo) e ciência, focaliza o plano da linguagem (o modo como empregamos os termos "medicina" e "ciência" em sentenças bem-formadas na língua comum) ou o plano da realidade (o modo como as coisas são). Em segundo lugar, nos dois casos há problemas sérios.

Suponha que Aristóteles focalize o plano da realidade. A tese

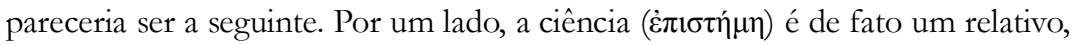
que se correlaciona ao cognoscível em geral: a ciência é aquilo que precisamente é por ser de outra coisa (o cognoscível). Por outro lado, a medicina não seria um relativo (e não haveria um correlativo apropriado que a ela se relacionasse), pois ela não seria aquilo que precisamente é por ser de outra coisa. Ora, o problema é que há algo na realidade, o curável (que é uma especificação do cognoscível), que pode perfeitamente ser identificado como o correlativo apropriado da medicina (cf. Metafísica 1032b5-6ss.). Além do mais, a tese seria absurda, se pretendesse estabelecer que o objeto que a medicina estuda não é um gênero de coisas reais que se relaciona à nossa cognição e delimita uma ciência particular. A suposta tese de Categorias 11a23-32 não faz nenhum sentido, aplicada ao plano da realidade.

Suponha, então, que Aristóteles focalize o plano da linguagem. A tese, neste caso, seria que a medicina não se expressa como um relativo. Mas essa tese poderia ser tomada de dois modos. De um modo, a medicina não se expressaria como um relativo porque não haveria um correlativo apropriado que fosse por assim dizer encapsulado no uso do termo "medicina", de tal modo que se pudesse explicitar, nos contextos apropriados, que "a medicina é a ciência de X'. Mas, tomada desse modo, a tese é claramente falsa. De outro modo, a medicina não se expressaria como um relativo porque a expressão "medicina de algo" não pode ser usada com sentido. Por outro lado, a ciência, em contraste com sua espécie, se expressaria como um relativo, porque todo uso do termo 
"ciência" encapsularia uma remissão ao seu correlato apropriado, de tal modo que toda ocorrência de "ciência" poderia ser substituída por "ciência de algo" (cf. 11a25-26) ou, mais precisamente, "ciência do cognoscivel".

Neste caso, seguindo o padrão que Aristóteles propõe em Categorias 11a27-28, a tese parece ser que "a medicina não se diz medicina de algo". No entanto, Aristóteles parece se precipitar sobre uma lacuna abissal, pois da tese de que: "medicina";

(i) não se usa a expressão "de algo" como complemento de

passamos para:

(ii) a medicina não é um relativo, que fosse aquilo que precisamente é em relação a outra coisa.

Ora, de fato, não se usam expressões como "quero aprender medicina de algo", ou "o Dr. Fausto tem a domínio da medicina de algo". Mas qual é o contraste, exatamente, com a ciência? Nas sentenças "quero aprender a ciência de algo", ou "o Dr. Fausto tem a domínio da ciência de algo", ou bem "de algo" é um mero substituto para uma expressão determinada ("quero aprender a ciência dos números", "o Dr. Fausto tem domínio da ciência do curável") e a indeterminação se justifica por alguma razão contextual, ou beiramos o nonsense. Por outro lado, em contextos bem determinados, a sentença "toda ciência é (ciência) de algo" é a expressão da característica intencional de nosso pensamento: toda ciência, enquanto estado de nossa alma, se relaciona a algo fora dela mesma, isto é, se relaciona aos objetos cognoscíveis. Não há razão para ser diferente com a medicina, se ela é uma ciência. De fato, também a medicina se relaciona a algo fora dela mesma, isto é, se relaciona ao seu objeto apropriado, que é a saúde ou o curável. A sentença "a medicina é do curável" não apenas faz sentido, como é verdadeira. Portanto, da tese de que a expressão "medicina do curável" não é usada em nenhuma sentença bemformada etc., não se segue a tese de que a medicina não seja um relativo. Cf. Kirwan [1993], p. 166-7, Ackrill [1963], p. 108-9.

De fato, a expressão "de algo" (em grego, $\tau$ เvos), parece ser fonte de perturbações sofísticas: em 1021a34, havia um deslize entre seu uso objetivo e subjetivo; em outros casos, como aqui, Aristóteles parece flutuar entre vários usos da expressão "de algo": (i) como placeholder ou variável livre que introduz, na sintaxe, um predicado completo - a ser substituído, nos contextos apropriados, por expressões como "do cognoscível", "do curável" etc., em sentenças como "a ciência é do cognoscível", "a medicina é do curável"; (ii) como placeholder ou variável livre que indica indeterminação, quando "ciência" se refere a uma de suas espécies, como em "a medicina é ciência de algo".

Creio que a melhor atitude do intérprete consiste em julgar que 
Aristóteles apenas relata certas dificuldades lingüísticas concernentes aos correlativos e suas expressões apropriadas. Tomar muitas das afirmações deste capítulo em seu valor de face como se fossem teses de Aristóteles pode levar a destinos infelizes.

\section{Capítulo 16}

1021b15: "bom desempenho": essa expressão traduz o advérbio grego " $e u$ ", que indica competência e excelência na performance de alguma atividade (Cf. EN 1098a12, 1106a16ss.). Uma tradução supostamente mais literal - como "algo se denomina completo pela excelência e pelo bem" - seria aceitável para o leitor bem treinado que já poderia adivinhar que o texto grego tem o advérbio "eu". Mas tal tradução corre o risco de transmitir comprometimento com outras noções de bem, o que não é desejável, sobretudo porque no trecho seguinte Aristóteles transfere esse uso de "completo" para coisas más, isto é, moralmente más, como o sicofanta e o ladrão. O mesmo uso do advérbio "eü" é retomado em 1021b31.

1021b18-20: "é um sicofanta completo etc.": essa passagem é bem útil para compreender como a filosofia de Aristóteles era sensível a sutilezas da linguagem - ou, por outras palavras, como há um rico filão a ser explorado no terreno da filosofia da linguagem em Aristóteles. A passagem apenas nota que o adjetivo "completo" (como muitos outros) é sempre dependente de algum outro termo aplicado a algum objeto. Em alguns casos, como o outro termo em questão denota alguma má qualidade moral (como a do sicofanta e a do ladrão), fica claro que o adjetivo "completo" tem um uso sincategoremático (na nomenclatura de Quine, [1960], \$27, p. 132). Aristóteles tem plena consciência de que certos adjetivos têm forças distintas quando se aplicam diretamente a objetos e quando se aplicam a objetos já previamente qualificados por algum termo. Cf. Da Interpretação 20b33-36 ("bom" e "bom sapateiro"), e o eco desse mesmo tema em Ref. Sofísticas 177b13-15 (cf. Fait [2007], p. 187).

1021b20-21: "a excelência é certo perfeccionamento": "perfeccionamento" traduz o termo "teleiosis", que, neste contexto, poderia ser bem traduzido também por "completude". No entanto, como usei "completude" para traduzir várias ocorrências de "telos" logo mais abaixo, e, além do mais, como "teleiosis" neste contexto sugere um processo pelo qual algo atinge sua perfeição pelo bom desempenho de sua atividade própria etc., julguei melhor optar por "perfeccionamento" neste caso.

1021b22-23: "nenhuma parte da estatura que lhe é natural": o uso do termo "megethos" é peculiar nesta passagem. Pela associação com "meros" (parte), seria plausível julgar que "megethos" se refere ao conceito de grandeza 
como noção abstrata da categoria da quantidade etc. No entanto, se Aristóteles estivesse a dizer apenas que "cada substância é completa quando [...] não lhe falta nenhuma parte da grandeza que lhe é natural" (no sentido de noção abstrata da categoria da quantidade etc.), ele apenas estaria a assinar que "teleios" é usado de modo oposto a "kolobos" (mutilado), isto é, àquilo em que falta alguma parte não essencial etc. (cf. 1024a11 ss.), e não se poderia compreender por que ele considera tal sentença uma justificação da anterior, segundo a qual "a excelência é certo perfeccionamento". É claro, portanto, que "megethos" é usado em 1021b23 para se referir à grandeza de algo no sentido de importância ou poder (cf. Ross, 1924, p. 332; para usos paralelos do termo, ver Poética 1149a 19, b25, e Lucas, 1968, p. 84). ${ }^{4}$ Em Português, o termos "grandeza" e "magnitude" também podem ser usados metaforicamente nessa mesma direção, indicando importância, poder, alcance, envergadura e excelência. No entanto, o termo "estatura" me parece ainda mais claro nessa direção, e tem a vantagem de captar um uso ordinário do termo também em grego (a estatura de Fulano pode ser tanto sua altura, como sua importância em dado contexto).

1021b23-24: "denominam-se completas as coisas nas quais está presente sua completude": "completude" traduz "telos", que é tradicionalmente traduzido por "fim" ou "finalidade". No entanto, evito essas opções, porque elas sugerem (se é que não se comprometem com) uma noção de teleologia que é estranha a Aristóteles, na qual a finalidade de $X$ é extrínseca a $X$. O que o termo "telos" quer dizer imediatamente em muitas de suas ocorrências é exatamente o acabamento intrínseco que faz $X$ ser $X$, o qual nada deve a finalidades extrínsecas a $X$. Outras ocorrências querem dizer realização ou sucesso pleno na realização de algo (em inglês, "fulfilment" or "achievement", cf. Kirwan [1993], p. 167, Makin [2006], p. xxviii).

1021b25-30: este trecho deve ser comparado com Física II.2, 194a2933 e, a rigor, permite atingir uma melhor compreensão do mesmo. Aristóteles fala que a completude é um tipo de item último, deixando margem para outro tipo de item último que não seja a completude. Mais abaixo (1021b29-30), nota que também é completude "o último item em vista de que", que é um modo usual de introduzir a causa final. No entanto, finais ruins também são itens últimos que terminam uma série, e é nesse sentido que também a morte, por ser o final da vida, é por vezes denominada como telos. Em Física 194a30-32, Aristóteles menciona um poeta cômico que se deixou levar por uma piada fácil, que consiste em dizer que alguém "tem seu fim [i.e., encontra a morte], em vista da qual nasceu”. Cf. Angioni [2009], p. 241-2.

${ }^{4}$ Agradeço a Manuel Berrón e Fabian Mié por discussão sobre esse ponto. 
Também se pode aplicar a esses finais ruins a noção de completude para dizer que, precisamente enquanto são finais ruins, não lhes falta nada: usamos, na língua comum, expressões como "destruição completa", ou "destruiu-se completamente".

1022a1-3: "outras coisas se denominam completas de acordo com essas": Aristóteles aplica aqui o mesmo princípio usado em Metafísica IV.2, 1003a33-b10, ao apresentar o modo pelo qual as coisas se denominam entes. Como se sabe, desde Owen [1957], esse princípio foi chamado de teoria do sentido focal (focal meaning) do "ser". O que talvez não se sabe é que esse princípio está fortemente enraizado na observação de como a linguagem ordinária se comporta.

\section{Capítulo 17}

Para exame da definição de "limite", ver Morison, [2002], p. 139-140. 1022a6: "a forma de uma grandeza": essa ocorrência do termo "eidos" não parece designar nada mais senão a forma no sentido de configuração sensível, que apreendemos pelos sentidos.

1022a8-10: "bem como a essência de cada coisa etc.": cf. Metafisica VII.2, 1028b16-18. Parece haver algum eco dessas passagens também em 1017b17-21, embora lá Aristóteles não use o termo "limite" (mas usa expressões a que o termo "limite" é constantemente aplicado). No entanto, na passagem de Metafísica VII.2, Aristóteles reporta uma tese forte, segundo a qual o limite de $X$ (isto é, entidades matemáticas como a superfície, a linha e o ponto etc.) é que é a essência de $X$. Aristóteles certamente discorda dessa tese, mas concorda com outra muito mais trivial, a de que a essência de $X$ é, de certo modo, um limite para $X$, pois é o limite para o conhecimento de $X$.

\section{Referências}

ACKRILL. J. Aristotle's Categories and De Interpretatione. Oxford: Clarendon Press, 1963.

ALEXANDRE DE APHRODISIAS. In Aristotelis Metaphysica Commentaria, Michael Hayduck (ed.), Berlim: Georg Reims, 1891.

ANGIONI, L. “Metafísica V, 1-8”. Phaos 3, 2003, p. 5-21. . As Noções Aristotélicas de Substância e Essência. Campinas: Editora da Unicamp, 2008. Aristóteles: Física I-II. Campinas: Editora da Unicamp, 2009. 
. "Prioridade e substância na metafísica de Aristóteles", Dois Pontos 7 (3), p.75-106, 2010.

. "Phronesis e virtude do caráter em Aristóteles: comentários a Ética a

Nicômaco VI”. Dissertatio 34, p.303-345, 2011.

BEERE, J. Doing and Being: an Intepretation of Aristotle's Metaphysics Theta, Oxford:

Oxford University Press, 2009.

CASTELLI, L. Problems and Paradigms of Unity: Aristotle's account of the one. Sankt Augustin: Academia Verlag, 2010.

COOPE, U. Time for Aristotle: Physics IV.10-14. Oxford: Oxford University Press, 2005.

FAIT, P. Aristotele: Le Confutazioni sofistiche, Roma-Bari: Laterza, 2007.

HEATH, T. Mathematics in Aristotle. Oxford: Clarendon Press, 1949.

JOACHIM, H. H. Aristotle: On Coming-to-be and Passing-Away (De generatione et corruptione). Oxford: Clarendon Press, 1926.

KIRWAN, C. Aristotle: Metaphysics, Books $\Gamma, \Delta$ and E. 2nd edition. Oxford: Clarendon Press, 1993.

LUCAS, D. W. Aristotle: Poetics. Oxford: Clarendon Press, 1968.

MAKIN, S. "What does Aristotle mean by priority in substance?", Oxford Studies in Ancient Philosophy 23, 2003, p. 209-238. Aristotle: Metaphysics Book Theta. Oxford: Oxford University Press, 2006.

MENN, S. [sem data]. The aim and the argument of Aristotle's Metaphysics. Unpublished manuscript.

MORISON. B. On Location: Aristotle's concept of place. Oxford: Oxford University Press, 2002.

OWEN, G. E. L. [1957]. "Logic and metaphysics in some earlier works of Aristotle", in Nussbaum, M. (ed.), Logic, science and dialectic. Londres:

Duckworth, 1986, pp. 180-99.

PERAMATZIS, M. "Aristotle's notion of priority in nature and substance", Oxford Studies in Ancient Philosophy 36, p.187-247, 2008. . Aristotle's Notion of Priority. Oxford: Oxford University Press, 2011. 
QUINE, W. O. Word and Object. MIT Press, 1960.

ROSS, W. D.. Aristotle's Metaphysics (2 vols.), Oxford: Clarendon Press, 1924.

SHIELDS. C. Order in Multiplicity: Homonymy in the Philosophy of Aristotle.

Oxford: Clarendon Press, 1999.

SMITH, R. Aristotle: Topics, Books I and VIII. Oxford: Clarendon Press, 1977.

WILLIAMS, C. J. F. Aristotle's De Generatione et Corruptione. Oxford: Clarendon Press, 1982.

E-mail: angioni.lucas@gmail.com

Recebido: 10/2017

Aprovado: 11/2017 